\title{
Prevalence of dyslipidaemia and micronutrient deficiencies among newly arrived Afghan refugees in rural Australia: a cross-sectional study
}

Mehdi Sanati Pour ${ }^{1 \dagger}$, Surabhi Kumble ${ }^{2+}$, Sarah Hanieh ${ }^{2}$ and Beverley-Ann Biggs $2,3^{*}$

\begin{abstract}
Background: Afghanistan is the $15^{\text {th }}$ least developed country in the world, with poor sanitation and high rates of infectious diseases and malnutrition. However, little is known about the health of young Afghan refugees resettling in Western countries.
\end{abstract}

Methods: We used a cross-sectional study design to examine the health profile of newly arrived Afghan refugees presenting to a General Practice between $20^{\text {th }}$ April 2010 and 22 ${ }^{\text {nd }}$ March 2013 in rural Australia. Data collected included information on nutritional status and prevalence of infectious diseases. Challenges associated with health screening in a General Practice setting in this population were also documented.

Results: Data were available on 92 patients. Mean age of presentation was 22.6 years [SD 11.9], and the majority of patients were male (88\%). Mean total cholesterol, LDL cholesterol, HDL cholesterol and triglyceride concentrations were $4.4 \mathrm{mmol} / \mathrm{L}(95 \% \mathrm{Cl}, 2.9-7.3), 2.6 \mathrm{mmol} / \mathrm{L}(95 \% \mathrm{Cl}, 1.3-4.4), 1.24 \mathrm{mmol} / \mathrm{L}(95 \% \mathrm{Cl}, 0.7-2.0)$ and $1.19 \mathrm{mmol} / \mathrm{L}(95 \% \mathrm{Cl}, 0.4-4.7)$ respectively, and dyslipidaemia (defined as elevated total or low-density lipoprotein (LDL) cholesterol levels, or low levels of high-density lipoprotein (HDL) cholesterol) was seen in $27.5 \%$ of patients. There was also a high prevalence of vitamin D and B12 deficiency ( $50 \%$ and $18 \%$, respectively) in this cohort. Issues that impacted on provision and access to health care for refugees included cost, language barriers, patient mobility and mental health issues.

Conclusions: Dyslipidaemia and micronutrient deficiencies are significant health issues in young recently settled Afghan refugees, and routine screening should be considered for this population.

Keywords: Dyslipidaemia, Micronutrient deficiencies, Afghan refugees, Rural Australia

\section{Background}

Australia is the largest settlement country for refugees on a per capita basis [1]. In 2012, the Australian Government increased its humanitarian program to 20,000 places - a more than 40 per cent increase, and the largest increase in intake within 30 years [1]. Afghan refugees are expected to make up a large proportion of this intake in the foreseeable future. Worldwide, Afghans form the largest group of refugees [2], and the withdrawal of

\footnotetext{
* Correspondence: babiggs@unimelb.edu.au

${ }^{\dagger}$ Equal contributors

${ }^{2}$ University of Melbourne, Melbourne Academic Centre, at the Peter Doherty Institute for Infection and Immunity, Melbourne 3010, Victoria, Australia ${ }^{3}$ Victorian Infectious Diseases Service, Royal Melbourne Hospital, Melbourne 3050, Victoria, Australia

Full list of author information is available at the end of the article
}

NATO troops from Afghanistan in 2014 is likely to cause further political instability in the country.

Afghans first migrated to Australia in the 1860 s as employees, bringing camels to aid their exploration for resources. Another surge of migration has occurred in the last decade and between 2008-13, 12,063 Afghan migrants have settled in Australia [3]. The majority live in southern Australia, and are aged between 18 and 34 years [4].

Afghan refugees have unique health problems due to the political and socio-economic circumstances they have encountered in Afghanistan, and during their journey to Australia. The majority have fled war, violence and trauma and are dealing with grief, loss and forced separation from their homes [5]. Afghanistan's health status is one of the worst in the world which reflects poor nutrition through 
the life cycle and communicable diseases, compounded by the lack of provision of adequate primary health care and public health programs across the country. The life expectancy at birth for both males and females is 48 years and the maternal mortality rate per 100,000 live births is 460 [6]. The prevalence of tuberculosis is 352 per 100,000 population [6]. A 2012 study of 1200 adults in Kabul showed that $31.2 \%$ are obese (body mass index(BMI) $\geq 30$ $\mathrm{kg} / \mathrm{m}^{2}$ ) with twice as many women affected as men, $38.1 \%$ are overweight, and obesity was a risk factor for hypertension and diabetes [7].

The Australian Society of Infectious Diseases recommends screening refugees within the first month after arrival for tuberculosis, malaria, blood-borne viral infections, schistosomiasis, helminth infection, sexually transmitted infections, and other infections (eg, Helicobacter pylori) as indicated by clinical assessment, and catch-up immunisations where appropriate [8]. However, testing for glucose, cholesterol and triglycerides and other risk factors for non-communicable diseases is currently ad hoc, with no clear guidelines for this refugee group.

An increasing number of refugees are settling in rural areas in Australia, either through a formal relocation program, for employment, or even to escape racism and violence [5]. At the end of June 2011, 28370 Afghanborn individuals were living in Australia, and eighty percent of permanent migration was accounted for through Australia's Refugee and Humanitarian Programme. Fifty four percent of refugees were male, and the median age was 29.5 years. The Programme has two components, offshore resettlement and onshore protection. Since 2011 there has been a significant increase in the number of asylum seekers arriving by boat [4]. While there have been some studies documenting the settlement experience in rural areas [5], little is known about the health needs of Afghan refugees, especially in those settling in these areas, including in Mildura, a rural city $580 \mathrm{~km}$ north west of Melbourne with a strong dependence on agriculture. This paper is a pilot study in this area that aims to identify the most prevalent health issues in newly arrived Afghan refugees settling in this rural area.

\section{Methods}

This was a cross-sectional study. We performed a retrospective review of laboratory results that had previously been collected as part of routine clinical practice, on all Afghan refugees presenting to a busy general practice in Mildura. Newly arrived Afghan refugee patients who presented to a General Practice between 20/4/2010 and $22 / 3 / 13$ were included in the study. All refugees had previously spent time in various detention centres in Australia, mainly on Christmas Island.

As part of the initial refugee health screening consultation, routine laboratory tests included fasting glucose, cholesterol, thyroid stimulating hormone (TSH), malaria film and immune-chromatographic test, vitamin D levels, haemoglobin, serum ferritin and vitamin B12 concentration, stool microscopy and culture for gastrointestinal pathogens, serology for schistosomiasis, strongyloides, hepatitis $\mathrm{B}$, hepatitis C, syphilis, rubella, and urinary PCR for N. gonorrhoea and C. Trachomatis. Barratt and Smith Pathology performed the laboratory tests (http://www.bsp.com.au), and standard reference ranges were used. Tests for schistosomiasis and strongyloides were referred to the Victorian Infectious Disease Reference Laboratory, Melbourne.

The treating GP (MSP) identified patients meeting the inclusion criteria and entered demographic information from the medical records into an excel database. Laboratory results were provided by the laboratory in an excel spreadsheet. The data was cleaned and checked for missing entries and inconsistencies, and entered into a Stata, Version 13 (StataCorp, College Station, TX, USA) for analysis. Categorical data are presented as percentages with frequency, and continuous data are presented as mean and standard deviation (SD). The significance of the difference in proportions was tested by means of $P$ values calculated on $\mathrm{X}^{2}$ distributions and continuous data using the student $\mathrm{t}$-test.

Conditions were defined as follows: elevated fasting blood glucose: glucose $>7 \mathrm{mmol} / \mathrm{L}$; anaemia: haemoglobin $<130 \mathrm{~g} / \mathrm{L}$ for men, haemoglobin $<120 \mathrm{~g} / \mathrm{L}$ for women; iron deficiency: serum ferritin $<15 \mathrm{ug} / \mathrm{L}$; vitamin B12 deficiency: serum vitamin $B 12<150 \mathrm{pmol} / \mathrm{L}$; abnormal TSH: serum TSH $<0.3 \mathrm{U} / \mathrm{ml}$ or $>5.0 \mathrm{U} / \mathrm{ml}$; abnormal lipid levels: total cholesterol $\geq 5.5 \mathrm{mmol} / \mathrm{L}, \mathrm{HDL}<1 \mathrm{mmol} / \mathrm{L}$, $\mathrm{LDL}>3.5 \mathrm{mmol} / \mathrm{L}$, Triglyceride $>2.0$ [9]. Dyslipidaemia was defined as elevated total or low-density lipoprotein (LDL) cholesterol levels, or low levels of high-density lipoprotein (HDL) cholesterol. Vitamin D deficiency was categorised as either: mild (30 to $49 \mathrm{nmol} / \mathrm{L}$ ), moderate (12.5 to $29 \mathrm{nmol} / \mathrm{L})$ or severe $(<12.5 \mathrm{nmol} / \mathrm{L})$ [10]. Exposure to a infection (STI) was defined as positive urinary PCR for N.gonorrhoea or C.Trachomatis. Rubella immune was defined $\operatorname{IgG}>10 \mathrm{IU} / \mathrm{ml}$, and hepatitis B immune as hepatitis B surface antibody positive (HepBsAb), surface antigen negative (HepBsAg), and core antibody negative (HepBcAb); or HepBsAb positive, HepBsAg negative and $\mathrm{HepBcAb}$ positive; or HepBsAb negative, $\mathrm{HepBsAg}$ negative, and $\mathrm{HepBcAb}$ positive.

A semi-structured interview was also conducted with the treating GP in the practice by a member of the research team, to identify challenges associated with initial health screening in this population. These observations are presented in Table 1. Informed consent was obtained prior to undertaking the interview.

As this was a retrospective review of laboratory results previously collected as part of routine clinical practice, 
Table 1 Observations around challenges of initial health screening in a refugee population in a rural general practice

\begin{tabular}{|c|c|}
\hline Questions & $\begin{array}{l}\text { Observations from treating general } \\
\text { practioner }\end{array}$ \\
\hline \multirow{5}{*}{$\begin{array}{l}\text { Challenges to undertaking full } \\
\text { health screen in Mildura, Victoria }\end{array}$} & $\begin{array}{l}\text { - Cost of screening tests } \\
\text {-Lack of information available from } \\
\text { previous screening }\end{array}$ \\
\hline & -Language barriers \\
\hline & $\begin{array}{l}\text {-Lack of understanding of the health } \\
\text { system }\end{array}$ \\
\hline & - Lack of trust of health professionals \\
\hline & -Patient mobility \\
\hline \multirow[t]{2}{*}{ Prevalent mental health issues } & $\begin{array}{l}\text {-Anxiety } \\
\text {-Depression }\end{array}$ \\
\hline & -Post-traumatic stress disorder \\
\hline \multirow{4}{*}{$\begin{array}{l}\text { Strengths of the refugee health } \\
\text { program at the clinic }\end{array}$} & $\begin{array}{l}\text {-GPs and reception staff of various } \\
\text { ethnic backgrounds (e.g. Dari, Turkish, } \\
\text { Persian, Tamil) } \\
\text { • Bulk-billing of all patients }\end{array}$ \\
\hline & $\begin{array}{l}\text {-Extended opening hours (8am-8pm, } \\
7 \text { days/week) }\end{array}$ \\
\hline & $\begin{array}{l}\text { - Integrated mental health system in } \\
\text { clinic }\end{array}$ \\
\hline & $\begin{array}{l}\text {-Access to refugee health and } \\
\text { infectious diseases specialists }\end{array}$ \\
\hline $\begin{array}{l}\text { Other issues with refugee health } \\
\text { related to a rural setting }\end{array}$ & -Anxiety due to family separation \\
\hline
\end{tabular}

written informed consent was not obtained from patients. Ethics approval was obtained from the Royal Melbourne Hospital Human Research Ethics Committee.

\section{Results}

Ninety-two patients presented to the clinic for a refugee health assessment during the thirty-five month study period. Table 2 depicts the baseline characteristics of the patients. The mean age of presentation was 22.6 years [SD 11.9], and the majority of refugees were male (88\%). The majority of patients arrived by boat in Australia, and were detained in Christmas Island, or had spent time in detention or in community detention in Indonesia before being accepted as refugees in Australia. Patients were generally held in detention centres between 12 months and 3 years before being released into the community.

The most frequent laboratory tests performed are presented in Figure 1.

Overall, vitamin D deficiency (50\%) and abnormal cholesterol levels (27.5\%) were the most commonly identified health issues in these young Afghan refugees. Table 3 shows the prevalence of common health issues identified, stratified by gender.
Table 2 Baseline characteristics of 92 newly arrived Afghan refugees seen in a general practice clinic in Mildura, Victoria 2010-2013

\begin{tabular}{ll}
\hline Characteristic & Values $^{1}$ \\
\hline Demographic & \\
Age (years) & $22.6[11.9]$ \\
$0-10$ & $19(20.7)$ \\
$11-21$ & $28(30.4)$ \\
$22-32$ & $25(27.2)$ \\
$33-43$ & $15(16.3)$ \\
$>43$ & $5(5.4)$ \\
Gender & \\
Female & $11(12.0)$ \\
Male & $81(88.0)$ \\
Weight $(\mathrm{kg})^{2}$ & $63.3[18.2]$ \\
Height $(\mathrm{cm})^{2}$ & $162.9[20.2]$ \\
Body mass index $\left(\mathbf{k g} / \mathrm{m}^{2}\right)$ & $22.9[3.93]$ \\
Underweight $\left(\mathrm{BMl}<18 \mathrm{~kg} / \mathrm{m}^{2}\right)$ & $9(12)$ \\
Normal $\left(\mathrm{BMl} 18-25 \mathrm{~kg} / \mathrm{m}^{2}\right)$ & $43(57.3)$ \\
Overweight $\left(\mathrm{BMl}>25 \mathrm{~kg} / \mathrm{m}^{2}\right)$ & $23(30.7)$ \\
\hline
\end{tabular}

${ }^{1}$ Values are mean [standard deviation] or number (\%).

2 Data missing on 17 patients.

\section{Dyslipidaemia}

Mean total cholesterol, LDL cholesterol, HDL cholesterol and triglyceride concentrations (TG) were $4.4 \mathrm{mmol} / \mathrm{L}(95 \%$ CI, 2.9-7.3), $2.6 \mathrm{mmol} / \mathrm{L}$ (95\% CI, 1.3-4.4), $1.24 \mathrm{mmol} / \mathrm{L}$ (95\% CI, 0.7-2.0) and $1.19 \mathrm{mmol} / \mathrm{L}$ (95\% CI, 0.4-4.7), respectively. The prevalence of elevated total cholesterol, LDL and TG, and decreased HDL-C concentrations were $11.3 \%$, $13.9 \%, 6.3 \%$ and $13.8 \%$, respectively. Over one quarter of patients (27.5\%) had dyslipidaemia (defined as elevated total or LDL cholesterol levels, or low levels of HDL cholesterol). Elevated total cholesterol $\left(\chi^{2}=6.38 \mathrm{P}=0.01\right)$ and LDL-cholesterol $(X 2=7.99 P=0.01)$ levels were significantly associated with age (Figure 2).

\section{Other chronic disease risk factors}

More than twenty percent of patients were smokers and $30 \%$ of patients were classified as overweight (BMI > $25 \mathrm{~kg} / \mathrm{m}^{2}$ ). Prevalence of elevated fasting blood glucose in this population was low (2.5\%) (Table 4$)$.

\section{Nutritional deficiencies}

Nutritional deficiencies stratified by age (under or over 25 years) are presented in Figure 3.

Vitamin D deficiency was the most common deficiency. Mean vitamin D concentration was $49.6 \mathrm{nmol} / \mathrm{L}$ [14.7]. Mild vitamin D deficiency (30-49 $\mathrm{nmol} / \mathrm{L})$ was seen in $27.8 \%$ of patients, $21.1 \%$ had moderate deficiency (12.5 to $29 \mathrm{nmol} / \mathrm{L})$, and $<2 \%$ had severe deficiency 


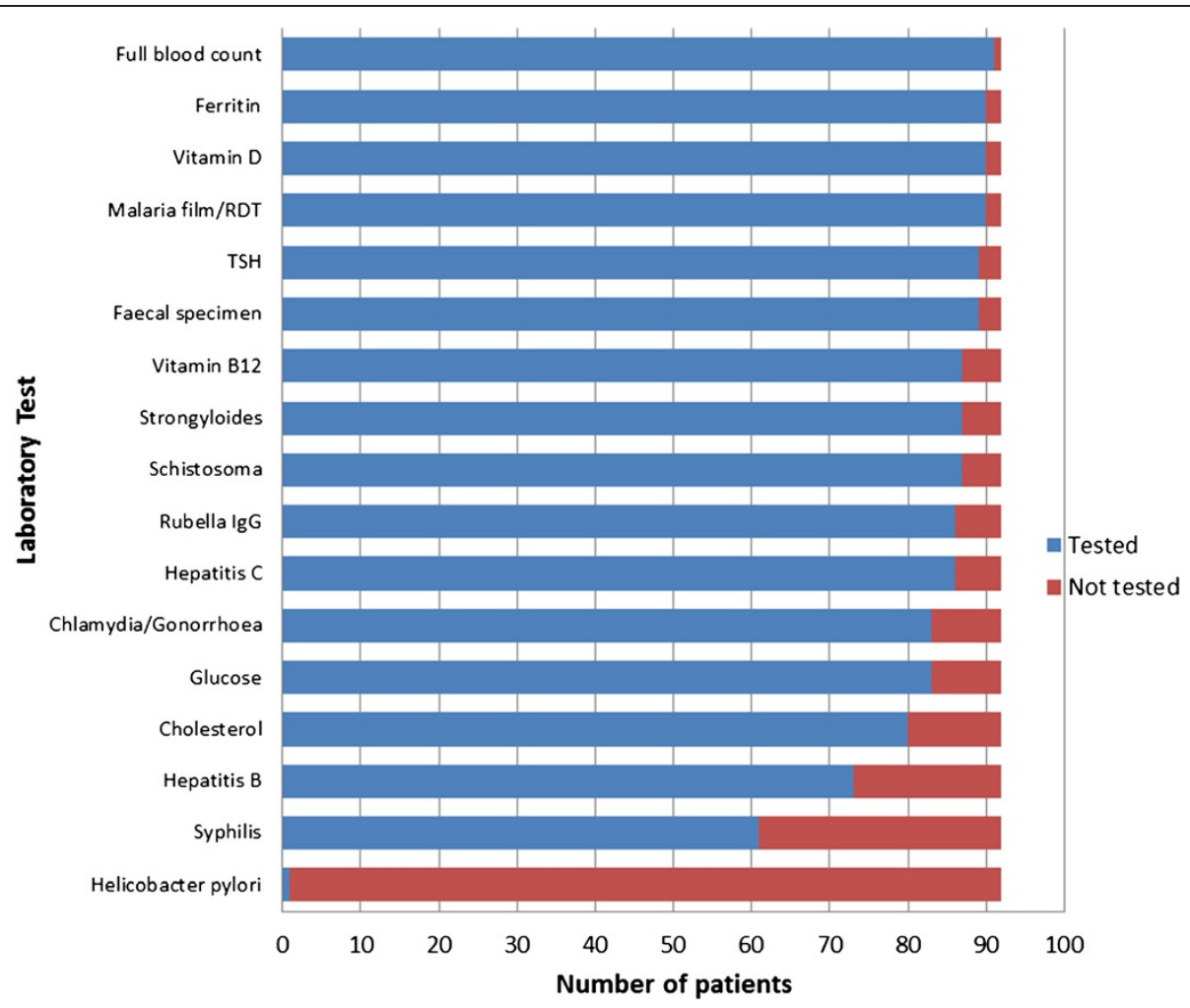

Figure 1 Most frequent laboratory tests performed by GP practice on newly arrived Afghan refugees to Mildura, Victoria, $2010-2013$.

$(<12.5 \mathrm{nmol} / \mathrm{L})$. The one case of severe vitamin D deficiency $(<12.5 \mathrm{nmol} / \mathrm{L})$ was in a 34 year old female patient. Vitamin $\mathrm{D}$ deficiency was more prevalent in female, compared to male patients $(\mathrm{X} 2=8.39 \mathrm{P}=0.03)$ The prevalence of vitamin B12 deficiency was $18.4 \%$, and anaemia occurred in less than $10 \%$ of patients (Table 3 ).

\section{Infectious diseases}

Giardia, schistosomiasis and strongyloidiasis were the most commonly identified infectious diseases. Eosinophilia was present in $7.7 \%$ of patients. No patients with eosinophilia were found to have a pathogenic stool parasite, or positive schistosomoma or strongyloides serology. No cases of malaria were documented.

\section{Access to health care}

A number of other issues impacting on provision and access to health care for these refugees were identified through an in-depth semi-structured interview with the treating GP. Table 1 summarises the observations identified during the interview, including cost, language barriers, patient mobility and mental health issues.

\section{Discussion}

Our results indicate that dyslipidaemia and vitamin D deficiency are common health issues in newly arrived Afghan refugees to rural Australia, and that language, cost and mental health issues are important considerations in provision and access to health care within this

Table 3 Five most common problems identified in newly arrived Afghan refugees in general practice, Mildura Victoria, 2010-2013

\begin{tabular}{|c|c|c|c|c|}
\hline & Total number (\%) & Male number (\%) & Female number (\%) & Chi squared \\
\hline Vitamin D deficiency (vitamin $D<50 \mathrm{nmol} / \mathrm{L}$ ) & $45(50.0)$ & $35(44.3)$ & $10(90.9)$ & $8.39 *$ \\
\hline Dyslipidaemia & $22(27.5)$ & $20(27.8)$ & $2(25)$ & 0.03 \\
\hline B12 deficiency (serum vitamin B12 < 150 pmol/L & $16(18.4)$ & $15(19.7)$ & $1(9.1)$ & 0.73 \\
\hline Giardia & $10(11.2)$ & $8(10.1)$ & $2(20)$ & 0.87 \\
\hline Anaemia ( $\mathrm{Hb}<130 \mathrm{~g} / \mathrm{L}$ male $\mathrm{Hb}<120 \mathrm{~g} / \mathrm{L}$ female) & $6(6.6)$ & $4(5)$ & $2(18.8)$ & 2.72 \\
\hline
\end{tabular}




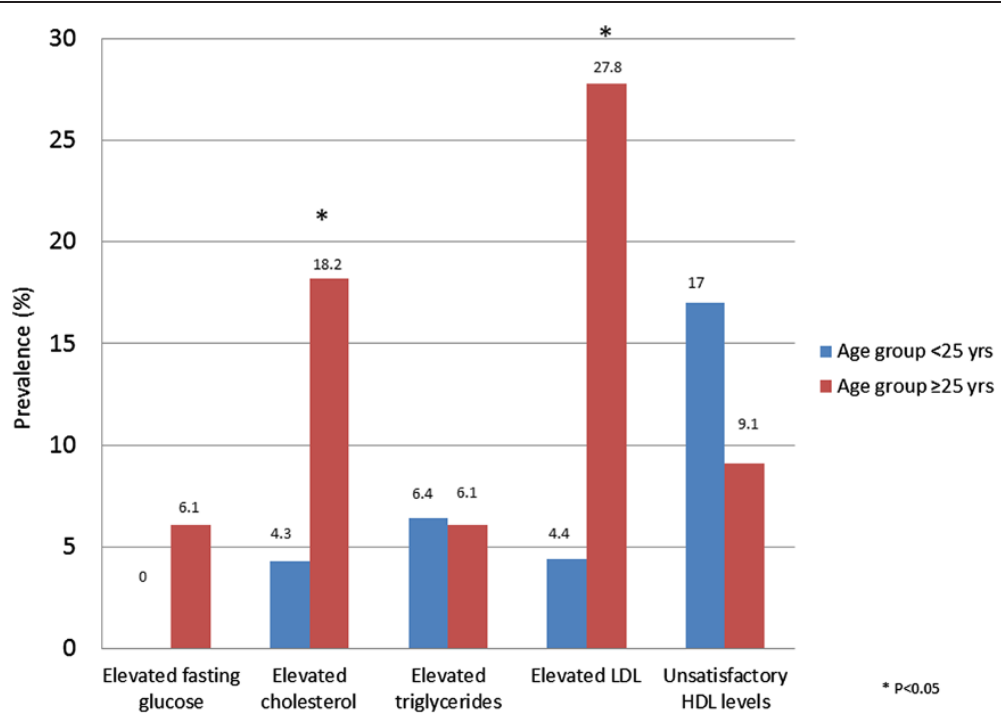

Figure 2 Prevalence (\%) of newly arrived Afghan refugee patients with dyslipidaemia or elevated glucose levels in Mildura, Victoria $2010-2013$.

community. To our knowledge, this is the first study to document health issues in newly arrived Afghan refugees settling in Australia.

In our study, almost $30 \%$ of patients had an elevated total cholesterol, LDL, or inadequate HDL levels at initial presentation for health screening, despite the majority of study participants being young adults with a mean age of 23 years. This high rate of dyslipidaemia most likely reflects under-nutrition in early life, as well the transition of the Afghan population to a higher fat diet and sedentary life style in the last few decades. Increasing evidence suggests that under-nutrition during pregnancy and in the first two years of a child's life may lead to disproportionate foetal growth and persisting changes in cholesterol metabolism, insulin responses to glucose, and other metabolic parameters, resulting in the programming of chronic diseases such as hypertension, coronary heart disease, and high cholesterol later in life [11-13]. In Afghanistan 20\% of infants are born with low birth weight (birth weight $<2500$ grams), rates of stunting in the first 5 years of life are close to $60 \%$, and $33.7 \%$ of children are underweight by 5 years of age $[14,15]$. This is compounded by transitions in dietary patterns, with increases in saturated fat, cholesterol and dietary energy density, and a reduction in exercise levels in adolescence and young adulthood, the so-called double burden of malnutrition $[16,17]$. Further research is needed to clarify whether the high rate of dyslipidaemia seen in these young adults is already present before leaving Afghanistan, or is a result of the migration process including dietary and exercise patterns in transit countries, such as Indonesia, and in Australian detention centres $[18,19]$.

The focus of refugee health in previous studies has mainly centred on infectious diseases, and there are limited studies with data on the prevalence of dyslipidaemia and non-communicable diseases in newly arrived refugees. Yun et al. found that half of the adult refugees (median age 31 years) screened on arrival in the United States had at least one chronic non-communicable disease (51.1\%), and 9.5\% had three or more non-communicable diseases [20]. Dodson et al. have demonstrated a high prevalence of hypercholesterolaemia (66\%) in Southeast Asian refugees resettling in the United States (median age 48 years) [21]. It has also been demonstrated that refugees who have experienced extensive food deprivation or insecurity are more likely to engage in unhealthy dietary practices following migration [22]. Dyslipidemia in rural

Table 4 Patients with chronic disease risk factors by age group

\begin{tabular}{lllll}
\hline Risk factor & Total & Age $>\mathbf{2 5}$ years & Age $<\mathbf{2 5}$ years & Chi squared \\
\hline Smoker & $18(23.7)$ & 28.0 & 21.6 & 0.39 \\
Overweight $\left(\mathrm{BMl}>25 \mathrm{~kg} / \mathrm{m}^{2}\right)$ & $23(30.7)$ & $12(24)$ & $11(44)$ & 3.14 \\
$\begin{array}{l}\text { Hypertension }(\text { systolic BP } \geq 140 \mathrm{mmHg} \\
\text { or diastolic BP } \geq 90 \mathrm{mmHg})\end{array}$ & $16(21.1)$ & $8(15.7)$ & $8(32)$ & 2.67 \\
$\begin{array}{l}\text { Dyslipidaemia } \\
\text { Elevated fasting blood glucose }\end{array}$ & $22(27.5)$ & $12(36.4)$ & $19(21.3)$ & 2.21 \\
\hline
\end{tabular}




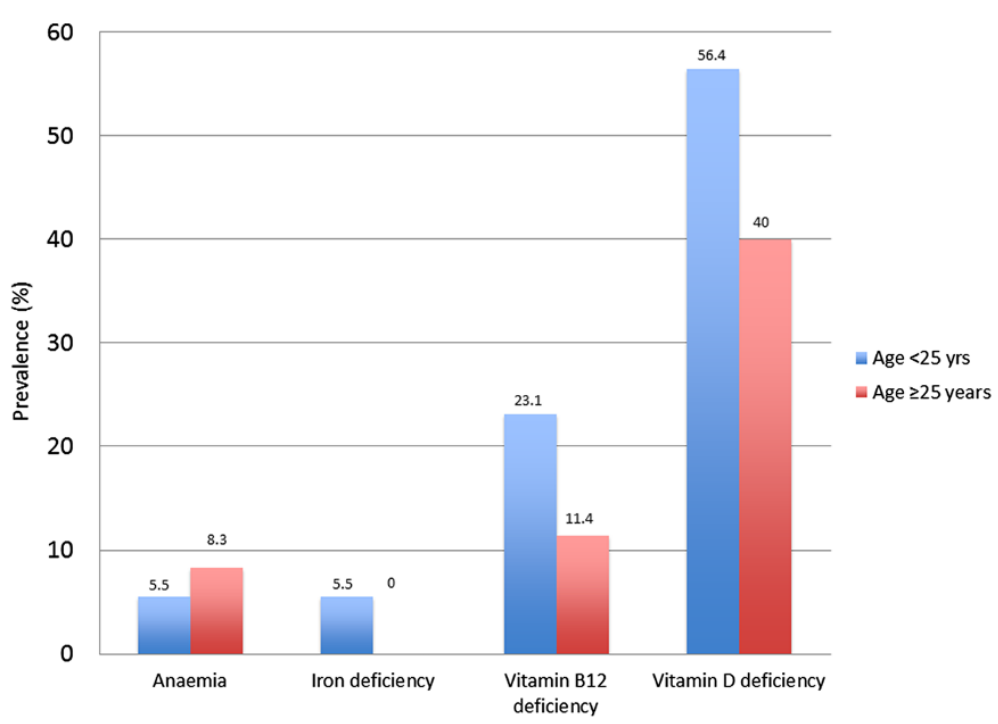

Figure 3 Nutritional deficiencies (\%) identified in newly arrived Afghan refugee patients in Mildura, Victoria, 2010-2013.

Australia has previously been demonstrated by Janus et al. in a non-refugee population, where hypercholesterolaemia was found to be $39 \%$, highlighting the need for improved risk factor management for hypercholesterolaemia and implementation of preventive strategies at the primary care level in rural populations [23]. There is an increasing global prevalence of chronic non-communicable diseases, and they now account for $61 \%$ of all deaths and $46 \%$ of the burden of disease among low and middle income countries [24]. Our findings highlight the need for careful screening within this population, particularly as refugees transition out of the early settlement period, and experience a shift to Western dietary patterns, with increased intake of fat and carbohydrate rich foods [25].

Vitamin D deficiency was the most common nutritional deficiency seen in this population, as has been demonstrated in other refugee studies [26-28]. More than $90 \%$ of females were deficient, and it is likely that cultural practices are a major risk factor, including wearing concealing clothing and spending more time in doors with limited daily sun exposure. Vitamin D is essential for skeletal health and bone mineralization. Vitamin D deficiency is often asymptomatic, but may present with vague symptoms such as muscle pain [29]. Severe deficiency may result in rickets in children and osteomalacia in adults, and deficiency has also been associated with infectious and autoimmune diseases, cardiovascular diseases, diabetes mellitus, cancer, and adverse pregnancy outcomes [30-35]. Our findings highlight the importance of regular testing for vitamin $\mathrm{D}$ deficiency in refugee populations, and consideration of routine Vitamin D supplementation in at risk groups [36,37].

We also found a relatively high prevalence of Vitamin B12 deficiency in this population, even though few were anaemic. Benson et al. (2010) have previously described low vitamin B12 levels (prevalence of 16.5\%) among newly arrived refugees from Bhutan, Iran and Afghanistan [38]. Food insecurity in countries of origin, inadequate nutrition during the asylum-seeking process, lack of consumption of animal products, and barriers to accessing B12 rich foods, e.g. due to cost, may contribute to the high prevalence of vitamin B12 deficiency in this population [26]. Vitamin B12 deficiency may be difficult to detect clinically as it commonly manifests with vague neurological and generalised symptoms such as paraesthesia, irritability, personality change, memory impairment, depression, fatigue, loss of appetite and weight loss. Severe deficiency can also lead to serious adverse consequences including subacute combined degeneration of the spinal cord and increased risk of myocardial infection and stroke. Infants born to vitamin B12 deficient mothers may also be at risk of severe, irreversible neurological damage [26,38-40]. Routine screening of B12 levels in this population is therefore important.

We documented a number of challenges observed in the provision of care to newly arrived Afghan refugees in this rural area including language, cost and understanding of the health system. Refugees who have previously resettled in similar areas may be useful in bridging these challenging language and cultural gaps (i.e. a local champion') [41]. Mental illness was also observed to be a significant health issue. Challenges to the provision of mental health care were noted to be a lack of refugeespecific mental health services in Mildura, as well as language and cultural differences. Effective prevention and management of mental health problems in newly arrived refugees in a primary care setting requires awareness of these issues [42].

Strengths of our study include the sample size, and the comprehensive screening undertaken. A limitation is the 
low number of females included (12\%) due to the small number of Afghan women being settled in Mildura, however the male refugees in this study are generally representative of the overall Afghan community, as fifty four percent of Afghan born refugees accounted for through Australia's Refugee and Humanitarian Programme are male.[4] A further limitation is the lack of access to other health information on participants such as liver ultrasound to assess fatty infiltration of the liver. However despite these limitations, our findings provide an important overview of the health status of newly-arrived Afghan refugees and potential barriers to care in a rural general practice setting. They will help to inform primary health care providers and policy makers, so that screening and provision of health care to Afghan and other refugees may be appropriately and effectively targeted.

\section{Conclusions}

Dyslipidemia and micronutrient deficiencies are important health issues in newly-arrived Afghan refugees to rural Australia, and routine screening should be considered in this population. This is a pilot study in this area and further research should explore the prevalence and morbidity from non-communicable diseases in Afghan refugees, as well as factors to improve provision and access to health care in this growing population.

\section{Abbreviations}

BMI: Body mass index; LDL: Low density lipoprotein; HDL: High density lipoprotein; TG: Triglyceride.

\section{Competing interests}

The authors declare that they have no competing interests.

\section{Authors' contributions}

MSP collected the data and was involved in the conception and design of the study. SK drafted and wrote the manuscript. SH performed the statistical analysis and redrafted the manuscript. BAB supervised the process of research and redrafted the manuscript. All authors read and approved the final manuscript.

\section{Acknowledgements}

We thank the staff of Tristar Medical Group and Christalla Hajisava for Departmental support.

\section{Author details}

${ }^{1}$ Tristar Medical Group, Mildura 3500, Victoria, Australia. ${ }^{2}$ University of Melbourne, Melbourne Academic Centre, at the Peter Doherty Institute for Infection and Immunity, Melbourne 3010, Victoria, Australia. ${ }^{3}$ Victorian Infectious Diseases Service, Royal Melbourne Hospital, Melbourne 3050, Victoria, Australia.

Received: 7 April 2014 Accepted: 26 August 2014

Published: 1 September 2014

\section{References}

1. O'Connor B: Refugee Program Increased to 20000 Places. ACT: Canberra; 2012.

2. The United Nations High Commission on Refugees: Asylum Levels \& Trends Report - Australia. Canberra: ACT: UNHRC Regional Office; 2010.

3. Asylum Trends- Australia: 2012-13 Annual Publication. In [https://www. immi.gov.au/media/publications/statistics/immigration-update/asylumtrends-aus-2012-13.pdf].
4. Afghan Community Profile. In [http://www.immi.gov.au/media/statistics/ country-profiles/_files/afghanistan.pdf ].

5. Refugee Resettlement in Rural and Regional Victoria: Impacts and Policy Issues. In [http://mccaugheycentre.unimelb.edu.au/_data/assets/pdf_file/ 0018/135252/RefugeeResettlement_Report_Mar08.pdf].

6. Afghanistan: health profile. In http://www.who.int/gho/countries/afg.pdf.

7. Islam SKM, Rasooly MH: Prevalence and risk factors associated with obesity among Adult Kabul Citizens (Afghanistan), 2012. Iran J Diabestes Obes 2012, 4(4):152-160.

8. Diagnosis, management and prevention of infections in recently arrived refugees. In [https://www.asid.net.au/documents/item/134].

9. Australian Heart Foundation: Lipid management guidelines. Med J Aust 2001, 175(Supplement):S57-S88.

10. Nowson CA, McGrath JJ, Ebeling PR, Haikerwal A, Daly RM, Sanders KM, Seibel MJ, Mason RS: Vitamin D and health in adults in Australia and New Zealand: a position statement. Med J Aust 2012, 196(11):686-687.

11. Barker DJ: Fetal origins of coronary heart disease. BMJ 1995, 311(6998):171-174.

12. Balbus JM, Barouki R, Birnbaum LS, Etzel RA, Gluckman PD Sr, Grandjean P, Hancock C, Hanson MA, Heindel JJ, Hoffman K, Jensen GK, Keeling A, Neira M, Rabadan-Diehl C, Ralston J, Trang KC: Early-life prevention of noncommunicable diseases. Lancet 2013, 381(9860):3-4

13. Gluckman PD, Hanson MA, Bateson P, Beedle AS, Law CM, Bhutta ZA, Anokhin KV, Bougneres P, Chandak GR, Dasgupta P, Smith GD, Ellison PT, Forrester TE, Gilber SF, Jablonka E, Kaplan H, Prentice AM, Simpson SJ, Uauy R, West-Eberhard MJ: Towards a new developmental synthesis: adaptive developmental plasticity and human disease. Lancet 2009, 373(9675):1654-1657.

14. Global database on child growth and malnutrition, Afghanistan. http://www.who.int/nutgrowthdb/database/countries/afg/en/.

15. The World Bank: Malnutrition in Afghanistan. In Malnutrition in Afghanistan: Scale, Scope, Causes, and Potential Reponse. Edited by The World Bank. Afghanistan: The World Bank; 2012.

16. Food and Agriculture Organization: The double burden of malnutrition: case studies from six developing countries. FAO Food Nutr Pap 2006, 84:1-334.

17. International Food Policy Research Institute: The Double Burden of Malnutrition in Asia. Washington, USA: International Food Policy Research Institute; 2003

18. Renzaho AMN, Nowson C, Kaur A, Halliday JA, Fong D, DeSilva J: Prevalence of vitamin $D$ insufficiency and risk factors for type 2 diabetes and cardiovascular disease among African migrant and refugee adults in Melbourne. Asia Pac J Clin Nutr 2011, 20(3):397-403.

19. Saleh A, Amanatidis S, Samman S: The effect of migration on dietary intake, type 2 diabetes and obesity: the Ghanaian health and nutrition analysis in Sydney, Australia (Ghanaisa). Ecol Food Nutr 2002, 41(3):255-270.

20. Yun K, Hebrank K, Graber LK, Sullivan MC, Chen I, Gupta J: High prevalence of chronic non-communicable conditions among adult refugees: implications for practice and policy. J Community Health 2012, 37(5):1110-1118.

21. Dodson DJ, Hooton TM, Buchwald D: Prevalence of hypercholesterolaemia and coronary heart disease risk factors among southeast Asian refugees in a primary care clinic. J Clin Pharm Ther 1995, 20(2):83-89.

22. Peterman JN, Wilde PE, Liang S, Bermudez Ol, Silka L, Rogers BL: Relationship between past food deprivation and current dietary practices and weight status among Cambodian refugee women in Lowell, MA. Am J Public Health 2010, 100(10):1930-1937.

23. Janus ED, Tideman PA, Dunbar JA, Kilkkinen A, Bunker SJ, Philpot B, Tirimacco R, Mc Namara K, Heistaro S, Laatikainen T: Dyslipidaemia in rural Australia: prevalence, awareness, and adherence to treatment guidelines in the greater green triangle risk factor study. Med J Aust 2010, 192(3):127-132.

24. Abegunde DO, Mathers CD, Adam T, Ortegon M, Strong K: The burden and costs of chronic diseases in low-income and middle-income countries. Lancet 2007, 370(9603):1929-1938.

25. Jellinger PS, Smith DA, Mehta AE, Ganda O, Handelsman Y, Rodbard HW Shepherd MD, Seibel JA: American association of clinical endocrinologists' guidelines for management of dyslipidemia and prevention of Atherosclerosis. Endocr Pract 2012, 18(Suppl 1):1-78.

26. Benson J, Maldari T, Turnbull T: Vitamin B12 deficiency - why refugee patients are at high risk. Aust Fam Physician 2010, 39(4):215-217. 
27. Benitez-Aguirre PZ, Wood NJ, Biesheuvel C, Moreira C, Munns CF: The natural history of vitamin $D$ deficiency in African refugees living in Sydney. Med J Aust 2009, 190(8):426-428.

28. Mason RS, Diamond TH: Vitamin D deficiency and multicultural Australia. Med J Aust 2001, 175(5):236-237.

29. Atherton K, Berry DJ, Parsons T, Macfarlane GJ, Power C, Hypponen E: Vitamin $D$ and chronic widespread pain in a white middle-aged British population: evidence from a cross-sectional population survey. Ann Rheum Dis 2009, 68(6):817-822.

30. Bhutta ZA: Vitamin D and child health: some emerging issues. Matern Child Nutr 2008, 4(2):83-85.

31. Camargo CA Jr: Vitamin D and cardiovascular disease: time for large randomized trials. J Am Coll Cardiol 2011, 58(14):1442-1444.

32. Gibney KB, Mihrshahi S, Torresi J, Marshall C, Leder K, Biggs BA: The profile of health problems in African immigrants attending an infectious disease unit in Melbourne, Australia. Am J Trop Med Hyg 2009, 80(5):805-811.

33. Mullins RJ, Camargo CA Jr: Shining a light on vitamin D and its impact on the developing immune system. Clin Exp Allergy 2011, 41(6):766-768.

34. Wayse V, Yousafzai A, Mogale K, Filteau S: Association of subclinical vitamin $D$ deficiency with severe acute lower respiratory infection in Indian children under 5 y. Eur J Clin Nutr 2004, 58(4):563-567.

35. Kovacs CS: Vitamin D in pregnancy and lactation: maternal, fetal, and neonatal outcomes from human and animal studies. Am J Clin Nutr 2008, 88(2):520S-528S

36. Tiong ACD, Patel MS, Gardiner J, Ryan R, Linton KS, Walker KA, Scopel J, Biggs BA: Health issues in newly arrived African refugees attending general practice clinics in Melbourne. Med J Australia 2006, 184(11/12):602-605.

37. Patience S: Vitamin D deficiency in at-risk groups. Community Pract 2013, 86(3):38-40

38. Benson J, Phillips C, Kay M, Webber MT, Ratcliff AJ, Correa-Velez I, Lorimer MF: Low vitamin B12 levels among newly-arrived refugees from Bhutan, Iran and Afghanistan: a multicentre Australian study. PLoS One 2013, 8(2):e57998.

39. Oh R, Brown DL: Vitamin B12 deficiency. Am Fam Physician 2003, 67(5):979-986.

40. Herrmann W, Obeid R: Causes and early diagnosis of vitamin B12 deficiency. Dtsch Arztebl Int 2008, 105(40):680-685.

41. Milosevic D, Cheng $\mathbb{H}$, Smith MM: The NSW refugee health service - improving refugee access to primary care. Aust Fam Physician 2012, 41(3):147-149.

42. Kirmayer LJ, Narasiah L, Munoz M, Rashid M, Ryder AG, Guzder J, Hassan G, Rousseau C, Pottie K: Common mental health problems in immigrants and refugees: general approach in primary care. CMAJ 2011, 183(12):E959-E967.

doi:10.1186/1471-2458-14-896

Cite this article as: Sanati Pour et al:: Prevalence of dyslipidaemia and micronutrient deficiencies among newly arrived Afghan refugees in rural Australia: a cross-sectional study. BMC Public Health 2014 14:896.

\section{Submit your next manuscript to BioMed Central and take full advantage of:}

- Convenient online submission

- Thorough peer review

- No space constraints or color figure charges

- Immediate publication on acceptance

- Inclusion in PubMed, CAS, Scopus and Google Scholar

- Research which is freely available for redistribution 